\title{
Lusotopie
}

Recherches politiques internationales sur les espaces issus de l'histoire et de la colonisation portugaises

$\mathrm{XVI}(2) \mid 2009$

Afrobrésiliennité ? Luso-afrobrésiliennité ?

\section{The Place of the International Relations Policy within National Trade Union Organisations}

The Case of the Cut in Brazil

o lugar da política de relações internacionais dentro das organizações sindicais nacionais. $O$ caso da CUT do Brasil

La place de la politique des relations internationales au sein des organisations syndicales nationales. Le cas de la CUT au Brésil

\section{Hermes Augusto Costa}

\section{Qrevues.org}

Electronic version

URL: http://lusotopie.revues.org/161
Publisher.

Association des rechercheurs de la revue Lusotopie, Brill, Karthala

Printed version

Date of publication: 1 June 2009

Number of pages: 41-64

ISSN: 1257-0273

\section{Electronic reference}

Hermes Augusto Costa, «The Place of the International Relations Policy within National Trade Union Organisations », Lusotopie [Online], XVI(2) | 2009, Online since 27 August 2009, connection on 26 Apri 2017. URL : http://lusotopie.revues.org/161 


\section{THE PLAGE OF THE INTERNATIONAL RELATIONS POLICY WITHIN NATIONAL TRADE UNION ORGANISATIONS The case of the CUT in Brazil *}

International relations policy is not restricted to the international trade union organizations. This paper discusses, on the one hand, the main obstacles to international relations policy within national trade unions. On the other hand, the phases and challenges of the international relations policy of the Brazilian Central Única dos Tabalhadores (United Workers Central) are analyzed in detail.

\section{La place de la politique des relations internationales au sein des organisations syndicales nationales Le cas de la CUT au Brésil}

La politique des relations internationales n'est pas limitée aux organisations syndicales internationales. Ce document aborde, d'une part, les principaux obstacles à la politique des relations internationales au sein des syndicats nationaux. D'autre part, les étapes et les défis de la politique des relations internationales de la Central Única dos Tabalhadores brésilienne (Centrale Unique des Travailleurs) sont analysés en détail.

\section{O lugar da política de relações internacionais dentro das organizações sindicais nacionais o caso da CUT do Brasil}

A política de relações internacionais não é um exclusivo das organizações sindicais internacionais. Neste texto discutem-se, por um lado, as principais contrariedades que, em geral, se colocam à construção de uma política sindical internacional nos sindicatos nacionais. Por outro lado, analisam-se as principais etapas e desafios que se colocam à política internacional da Central Única dos Trabalhadores (Brasil).

"We have a homeland, our country, but labour class has a bigger homeland, the planet itself"

(Vicente Paulo da Silva, former leader of the GUT)

$I^{n}$ an apt remark on Brazilian trade unionism in general and on the Central Única dos Trabalhadores (CUT, United Workers Central) in particular, Armando Boito Jr. stated that international relations is an important subject "waiting for researchers" (Boito Jr., 1999: 215). This idea - which suggests that we are in front of a scarcely studied subject - is relevant not only to Brazilian trade unionism in particular as well to trade unionism in general. The lack of interest in an International Relations Policy (IRP) on the part of researchers of the trade union movement may be

* This text is a brief summary of a full empirical research which took place in Brazil (São Paulo, Florianópolis and Porto Alegre), leading to the author's PhD entitled Sindicalismo global ou metáfora adiada? Os discursos e as práticas transnacionais da CGTP e da CUT, Faculty of Economics, University of Coimbra (Costa 2005). See also Costa 2008b. 


\section{Abbreviations}

AFL-CIO, American Federation of Labor-Congress of Industrial Organizations

Alca, Área de Libre Comercio de las Américas

CGSCS, Coordenadora das Centrais Sindicais do Cone Sul

GFDT, Confédération française démocratique du travail

GGT, Confederação Geral dos Trabalhadores do Brasil

CGT(P), Confederação Geral dos Trabalhadores Português

Glat, Central Latino-Americana de Trabalhadores

COB, Central Obrera Boliviana

Conclat, Congresso Nacional da Classe Trabalhadora

Concut, Congresso Nacional da CUT

Cosatu, Congress of South African Trade Unions

Grustal, Conselho para a Unidade Sindical dos Trabalhadores da América Latina

GUT, Central Única dos Trabalhadores (United Workers Central)

DGB, Deutscher Gewerkschaftsbund

Etuc, European Trade Union Confederation

EWCs, European Works Councils

FNV, Federatie Nederlandse Vakbeweging

FTAA, Free Trade Area of the Americas

HSA, Hemispheric Social Alliance

ICFTU, International Confederation of Free Trade Unions

ILO, International Labour Organisation

IMF, International Monetary Fund

IRP, International Relations Policy

ITSs, International Trade Secretariats (present Global Union Federations, GUFs)

Ituc, International Trade Union Confederation

MAI, Multilateral Agreement on Investments

Nafta, North American Free Trade Agreement

Mercosur, Common Market of the South

OECD, Organisation for Economic Co-operation and Development

Orit, Organização Regional Interamericana da Trabalhadores

PIT-CNT, Plenário Intersindical de Trabajadores-Central Nacional de Trabajadores

PT, Partido dos Trabalhadores (Workers' Party)

SRI/CUT, Secretaria de Relações Internacionais da CUT (International Relations Department)

WCL, World Confederation of Labour

WFTU, World Federation of Trade Unions

WSF, World Social Forum

WTO, World Trade Organisation 
explained, to a large extent, by the fact that the amount of attention devoted to such a policy within the range of many national trade union organisation policies is far from what might be expected, bearing in mind the "era of globalisation" in which we live. Whilst it is known that ambitions for emancipation and labour international solidarity remain alive in the "voice" of the trade union union movement, it is nevertheless a fact that it was capital, and not labour, that has become successfully internationalised. With this observation in mind, in the first part of this article some of the restrictions on the transnational trade unionism are identified. In the second part, I will focus on the main phases of the CUT's IRP in order to point out the main features of each phase.

\section{Constraints to international trade union policy}

According to Santos and Costa (2005: 40-41), even the theoretical premises on which working class internationalism was based did not hide some important restrictions. These premises were the following: a) the idea that the proletariat would be the great protagonist of a human emancipation destined to free the working class from the loss of humanity to which it had been subjected in the context of bourgeois society; b) the belief that the advance of capitalism would be synonymous with the homogenization of the proletariat; c) the idea that this homogenization would permit the creation of a community of interests organised as a "class" by agents of the collective struggle (the trade unions), while rejecting all forms of nationalism and nation-state rivalries (Hyman 1999: 95). It is true that originally the labour movement was conceived as international in structure and internationalist in aim (Waterman 1998: 17). However, not only did the proletariat reveal itself incapable of releasing the working class from capitalist oppression, but homogenization did not occur either, despite the confirmation of trade unionism as the principal organizing force of the working class. Furthermore, the fact that traditional 19th century union internationalism was tied to national spaces (Waterman 1998: 20; 26; 51) also meant that the internationalist ambition contained in the third premise was denied.

The disappearance of the first organisational forms of labour internationalism - the Internationals - also reinforced the difficulties faced by labour movement. The First International (1864) was split by enormous internal divergences between the Marxists, Proudhonists and Bakunists (Holthoon \& Linden 1988: vii). Probably, the disintegration of the First International

"was not due primarily to political divisions such as arguments over support for the Paris Commune. The national recognition and consolidation of unions were of far greater import. This constitution of unions as national entities appeared to diminish rather than strengthen the need for internationalism. When legal recognition was won and as national bargaining systems emerged, the view that problems could be fought and resolved at national level without reference to the international context dominated." (Lambert \& Webster 2006: 281)

On the other hand, the Second International (1889) was dominated by a spirit of collective fervour and it was the testimony of the reinforcement of the political parties (responsible for the political aspects of the social change) and the relative 
weakening of trade unions (more focused on economic and technical issues). According to Stevis and Boswell (2008: 53), the difficulties of trying to build socialist and labour internationalism in the face of nationalization were very evident in the history of this International. Trade unions from countries that did not have socialist parties were allowed to affiliate, but by allowing only one entity per country to join the Second International contributed to the territorialisation of global socialist politics. Under the absence of supranational commitments, the national dynamics overcame de international ones, resulting in most member parties supporting their own states during the First World War. The Third International (1919), in its turn, was dominated by party dogma (Nash 1998: 1). The international pressure over a revolutionary Russia and the necessity to coordinate actions that should be extended to other countries was a fundamental reason for the constitution of this International. The formation of this communist International joined the most internationalist and radical elements in the global socialist movement, until its total subjugation to the Soviet State (Stevis \& Boswell 2008: 59).

The world trade union confederations that followed in the second half of the 20th century, the World Federation of Trade Unions (WFTU), the International Confederation of Free Trade Unions (ICFTU) and the World Confederation of Labour (WCL), despite having different orientations and concepts, also came to display common features: a distancing between leaders and union bases; the persistence of influences resulting from the Cold War context, a tendency to reproduce the structure and behaviour of the nation-state and interstate agencies; an excessive dependence on the principles of a "North"-based trade unionism; inspiration in European and North-American strategies and ideologies originating in the 19th century and the first half of the 20th (social democracy, communism, social Christianity, and business unionism); the reduction of the complex reality of the world's working population to the model of the unionised male worker; etc. (Waterman 1998: 112-113, 2005: 220-227). While the ICFTU, WFTU and WCL have contributed to moulding contemporary labour internationalism, their practices lead towards a series of errors from the past that it is important not to repeat. Not infrequently the international labour movement has preferred closeddoor tactics and diplomacies instead of using the power of the working class; it has preferred negotiation with restricted and financially secure trade union circles to the detriment of wide-ranging debate within the union movement as a whole; it has preferred to hold discussions about important issues behind closed doors, instead of extending them to the different levels of the union structure (Cosatu 2001: 2; 3).

The proclaimed "democratisation" of ICFTU - particularly as a result of the XVIII Congress (December 2004), where a resolution was passed committing the ICFTU to the constitution of the new International Trade Union Confederation (Ituc), consisting of the ICFTU, the WCL and all the remaining independent national and democratic unions (ICFTU 2004a, 2004b) - may therefore represent a decisive step forward towards greater unification and less bureaucracy in the international trade union movement. In fact, the promotion of organisation and democratisation within international trade union movement were two important purposes established by the Ituc when this international organisation was born in November 2006. However, I would say that the most relevant challenge faced by the "New 
International" is probably on the capacity to cut with the traditional practices of the international trade union actors mentioned above (Costa 2008a; 2009). Cutting with the past is the only feasible way to face the future more quietly.

Together with the limitations associated with the theoretical premises of working class internationalism and the criticisms levelled at the praxis of the main international union organisations, other obstacles to international trade unionism and the creation and implementation of international policies by national union organisations are also evident, including the following: a) the greater priority given to national policies, bearing in mind that legislation, salaries and working conditions are all defined on a national level; b) the scant theoretical production on transnational unionism, which is partly explained by the small amount of international trade union "exchanges"; c) a lack of financial resources to support initiatives associated with international cooperation; d) the insufficient importance attributed to labour solidarity by organisations in different parts of the world, to the detriment of the (sometimes excessive) emphasis on opposing visions between the Northern and Southern unionism; e) the fact that multinational companies frequently resort to measures that exploit the working class; f) the institutional weakness of labour market institutions capable of safeguarding the interests of labour worldwide (in my view the International Labour Organisation, ILO, is the exception!), the inexistence of a cohesive supranational trade union identity (Santos \& Costa 2005: 25-26; Costa 2006: 244-247, 2008b: 38-44).

Some of these obstacles were pointed out by the CUT unionists I have interviewed. They were almost unanimous in recognising that international relations have little status within the political orientations of the CUT. In fact, I realised that the importance of the 'national' still has a decisive influence on the supranational interventions of national trade union organisations, as the following statements confirm:

"We have to understand the extent of our own problems first before we can discuss international matters."

"The main priority for any trade union is national affairs first of all; it's the company, the category, the city, the region and the country. International affairs only come after that." ${ }^{2}$

"Even though they are supported by an internationalist logic, the activities of the trade unions remain tied to a national perspective."

"We shouldn't forget that Brazil only opened up to the rest of the world very recently. We lived through a dictatorship from 1964 to 1985 and as it was a dictatorship there was very little opportunity to learn about anything outside Brazil. You hardly ever left, except for training courses in Washington, at the AFL-CIO $^{4}[\ldots]$. There's a

1 Vicentinho, ex-president of the CUT, interviewed in the Boletim Mercosul, 17th February 2000: 3 .

${ }^{2}$ CUT International Relations Secretary, interview, June 2000, São Paulo, GUT Head Office.

${ }^{3}$ Centro de Estudos de Cultura Contemporânea (Cedec) researcher, interview, June 2000, São Paulo.

${ }^{4}$ AFL-CIO, American Federation of Labor-Congress of Industrial Organizations. 
whole generation of people inside the CUT with that background [...]. We had a very insular kind of social and cultural education." ${ }^{.5}$

When I asked CUT trade unionists and former trade unionists what would be the main defining elements of an IRP, they outlined the following: regular actions on an international level; solidarity underlying these actions; financial support for the implementation and consolidation of transnational activities; the definition of objectives and strategies for international intervention; the selection of allies to implement these objectives; the use of particular mechanisms and procedures to achieve these objectives and to maximise relations with allies. Yet, even as they identified these elements, those I interviewed stated that they would not be easy to put into practice (see also Costa 2008b: chapter 2).

Taking all these constraints into account, what kind of space was reserved by the CUT for its IRP? This is the next point I shall consider.

\section{Stages and challenges in the CUT's international relations policy}

Despite the reservations expressed by the CUT trade unionists concerning the position of the IRP within union policies as a whole, "international relations" has been part of the CUT's agenda ever since it was founded. Moreover, as evidence of its concern to map out a trajectory for its international activities, two major union publications do, in fact, provided a detailed and systematic history of the CUT's IRP (CUT 1992; 2003e). Although they may not coincide exactly with those proposed by the $\mathrm{CUT}^{6}$, the various phases of the CUT's IRP that I propose here take these publications into consideration, in addition to many other union documents I have consulted, not only in the CUT Centro de Documentação (Information Centre, São Paulo, CUT Head Office), but also at the CUT Escola Sul (Training School, Florianópolis), amongst other places. I refer to the Reports and Cadernos de Teses (policy documents) from the National Congresses (that take place every 3 years) and National Plenary Meetings (that take place between congresses), the Boletim Mercosul (published between July 1998 and April 2000), the Textos para Debate Internacional ("Papers on the International Debate", which has been published since 1992), some of the Cadernos de Formação Sindical ("Union Training papers") which deal with the subject of regional integration, etc. In addition to this, the meetings and interviews held with CUT trade unionists, advisors, trainers, former trade

${ }^{5}$ CUT Organisational Secretary, interview, June 2000, São Paulo, CUT Head Office.

${ }^{6}$ Particularly in a study published in 2003 by the CUT International Relations Department (Secretaria de Relações Internacionais, SRI/CUT), three major phases are proposed for the CUT's international policy, within which other periods can be defined: the first phase (1983-1988), characterized by the need to create bonds of international solidarity that would strengthen the newly-created union organisation; the second phase (1988-1992), in which a strategy for bilateral relations began to be defined and constructed, characterised by autonomy in the face of the large world union confederations; and a third phase (1992-2003), corresponding to the decision to proceed with international affiliation, active participation in the process of regional integration (the Common Market of the South, Mercosur, and the Free Trade Area of the Americas, FTAA) and the creation of an intervention strategy to deal with the phenomenon of globalisation (CUT 2003e). 
unionists and former advisors, as well as studies on the Brazilian trade union movement have all contributed decisively to the research I have carried out into the CUT's IRP.

My own proposed division for the CUT's IRP is based on five phases: the first (1983-1988), governed by the need to establish the CUT and to make its union and political plans known to the outside world; the second (1988-1991), characterised by efforts to consolidate the GUT, which would translate into a systematic elaboration of the first directives on international activities; the third (1991-1992), defined by the decision to forge organisational links with international trade unionism, namely through affiliation to the ICFTU and the Organização Regional Interamericana de Trabalhadores (Orit, the Inter-American Regional Workers' Organization); the fourth (in particular from 1992 to the end of the decade/beginning of the 21 st century), placing particular emphasis on the processes of regional integration, represented by strong support for Common Market of the South - Mercosur, Mercado Común del Sur - and the denunciation of the FTAA); and the fifth (end of the 1990s/beginning of the 21 st century to the present), in which possible forms of interaction with other organisations in civil society have assumed a new political importance, although this phase still retain many of the features of the previous phases.

But before presenting CUT's IRP phases, I would like to note that those phases are not totally "pure". First, because there is not a complete breakaway between phases (in some cases the continuity between phases is evident, despite the identification of new additional features in order to emphasize the differences between phases). Second, because trade union politics (both national and international) are influenced not only by internal factors - directly related with trade union action (composition, structure and strategic aims of trade unions, ideological orientations, union restructuring, etc.) -, but also by external factors (state, political parties, employer, church, etc.) (Stevis 2002: 132-133). Of course, in terms of its constitution (statutes), CUT is an autonomous organisation, and it declares itself independent from the state, government, political parties, employers, religious institutions, etc. However, its political options are unavoidably conditioned by some of these external factors, being the close relationship with political parties on of these factors: as a fact, the internal tendencies ${ }^{7}$ of the CUT are in part the result of different party (external) influences, especially by the Partido dos Trabalhadores (PT, Workers' Party), founded in 1980, three years before CUT's foundation. And, of course, the CUT's IRP is also influenced by such external forces ${ }^{8}$.

${ }^{7}$ Presently (May 2009), these political tendencies are the following: Articulação Sindical (the main tendency), O Trabalho, Articulação de Esquerda, CUT Socialista e Democrática, Tendência Marxista, Esquerda Marxista.

${ }^{8}$ Some of the CUT leaders are both members of CUT and PT, i.e., they dress simultaneously the shirt of the party and the shirt of trade union. João Felício, the International Relations Secretary in charge between August 2006 and August 2009, is at the same time the national trade union secretary of PT. And in 2003 he had already been nominated by the President Lula da Silva as member of the Conselho de Desenvolvimento Ecomomico e Social, one of the new instruments of social dialogue of the Lula's government <www.cut.org.br/content/category/14/93/237/>. 


\section{Phase 1: The first steps}

Symbolised by the first Congresso Nacional da Classe Trabalhadora (Conclat-National Congress of the Working Class) which took place on 26-28 August 1983, the foundation of the CUT opened up "the possibility of a new kind of politics", by breaking with the political models of the past and enabling workers to express themselves as "independent political citizens in the life of the nation" (CUT 1984a: 8). Later, within the context of the 1st Congresso Nacional da CUT (Concut, CUT National Congress) held in August 1984, the CUT revealed a greater concern with perspectives and proposals to be implemented on national, state and regional levels than with international issues. On a national level, for example, there was a great willingness to "build the CUT in all states and regions and bring it to all categories, professions and workplaces" (CUT 1984b: 6), whilst at state level there was a call for the constitution of CUTs in every states. In a context in which the main objective of the CUT was to unify the struggles in Brazil (Giannotti \& Neto 1990: 54-57), proposals for arranging encounters with Latin American workers - promoted by the CUT, the Plenário Intersindical de Trabajadores-Central Nacional de Trabajadores (PIT-CNT) of Uruguay and the Central Obrera Boliviana $(\mathrm{COB})$ with the aim of fighting payment of the Latin American countries' external debt and the impositions of the International Monetary Fund (IMF) - were the main issues that called for international labour solidarity (CUT, 1984b: 2).

At the time of the 2nd Concut (August 1986), the campaign for non-payment of the external debt was still viewed by the CUT as one of the main political tasks of the trade union movement, since it represented "one of the most important mechanisms used by imperialism to ensure its economic and political dominance over the region [...] the main obstacle to development in our nations and to the possibility of improving the living standards of our people" (CUT 1986: 20). To tackle this, the GUT proposed to hold meetings between Latin American and Caribbean workers, calling for and welcoming the involvement of the regional Latin American trade union organisations - the Conselho para a Unidade Sindical dos Trabalhadores da América Latina (Crustal), the Central Latino-Americana de Trabalhadores (Clat) and Orit - respectively the regional organisations of the WFTU, the WCL and the ICFTU in the American continent. In this way, it aimed to promote unity between the various trade union confederations opposed to the external debt and to interference by the IMF. At the same time, CUT supported a proposal from the WFTU to hold an International Day against payment of the external debt on 23 October of that year. In addition, it also referred to the fact that issues related to technologic modernisation, unemployment, the unskilled labour force and the concentration of the means of production in the hands of the multinational companies, as well as the arms race, should also "necessarily involve the joint international strategies of the union movement" (CUT 1986: 23). In spite of this, the CUT maintained its autonomy vis-à-vis the international and regional trade union confederations, preferring to develop bilateral contacts with the various world trade union confederations in order to safeguard the working class struggle and respect for its class principles on an international level.

The type of unionism supported by the GUT represented a clear break with the traditional concepts of trade unionism in Latin America, once it prepared the 
way for a new world view and the construction of a consistent IRP (Castro \& Wachendorfer 1998: 25). Even so, in this first phase, despite the defence of an internationalist discourse based on class solidarity, peace and the struggle for the self-determination of peoples "the CUT did not succeed in formulating a clear policy that could establish the tacit and strategic objectives of its international relations, and restricted its activities to diplomacy and the search for solidarity and international recognition" (CUT 1992: 6). It may therefore be said that this was a preparatory phase in its IRP, in which the main priority was the search for national union identity through the "CUT project". The international activities of the CUT were very much dependent on "the discourses, documents and intentions of its leaders" and in this sense "the CUT had international relations but no international relations policy". Gradually, and within the context of the 2nd National Plenary Meeting in 1987, the CUT began to establish itself internationally, particularly through the significant part it played in organising the Latin American and Caribbean Conference on the External Debt in Campinas, together with the Confederação Geral dos Trabalhadores do Brasil (CGT), the PIT-CNT (Uruguay) and the COB (Bolivia) (Bargas 1991: 11, Véras, 2001: 54). This was, however, an isolated action, since activities related to international solidarity with groups such as the Palestinian people, Solidarnosc in Poland, the Cuban people, Chilean and Paraguayan workers, in support of the self determination of the people of Nicaragua, etc., were, in fact, more common ${ }^{10}$.

\section{Phase 2: Reinforcing and consolidating the CUT}

The second phase of the CUT's IRP took place between 1988 and 1991, coinciding with the consolidation of the CUT as organisation. During this time, the campaign of the Latin American countries for non-payment of the external debt once again predominated. A large number of initiatives and international meetings associated with this issue took place, with the aim of making workers throughout the continent more aware of the significance and implications of that problem. Therefore "it is absolutely essential for unions to be united in their opposition to the debt in order to carry forward the workers' struggle into every country, especially as we are still far from able to link concrete and everyday struggles to the problem of the debt" (CUT 1988b: 33). The idea of broadening the struggle as much as possible turned into calls for popular movements and political parties to unite and into encouragement for trade union confederations in the advanced capitalist countries to demonstrate their solidarity from within the First World. The international solidarity functioned once again as a cause for the CUT's action. Thus, its international solidarity policy was orientated towards, amongst other issues: the struggle against military dictatorships; the defence of the Sandinista revolution and the revolutionary struggle of the workers in El Salvador and Guatemala; the denunciation of the racist South African regime; and solidarity with the struggle of the people of Palestine (CUT 1988b: 31).

${ }^{9}$ Former CUT International Relations Secretary, interview, June 2001, São Paulo, CUT Head Office.

${ }^{10}$ SRI/CUT adviser, interview, June 2001, São Paulo, CUT Head Office; See also CUT 2003e: 27-29. 
However, it was the 3rd Concut that drew up some important points that enabled the SRI/CUT to establish priorities for international trade union activities, such as: the intensification of relations with organisations in Latin American countries; the deepening of bilateral relations with the European trade union organisations; the development of articulated activities through workplace organisations; and the interiorisation of international relations within the different organising levels of the CUT (CUT 1992: 6-7). This congress saw the beginnings of the definition of an IRP:

"We may have had relations with the trade union organisations but we had to have a policy. We had to know what we wanted in international terms, mainly because we were an independent organisation, we weren't affiliated to any world trade union confederation. However, we couldn't go along with the Cold War game that all the world trade union confederations were involved in [...]. We didn't have an international relations policy then. We only had international relations! You only have a policy when you know what you want and you build your objectives, your strategies. And that only started happening with the 3rd Congress." 11

When reading the CUT documents I was surprised that there were virtually no references to the Coordenadora das Centrais Sindicais do Cone Sul (CCSCS), founded in 1986 with the support of Orit. Part of the reason for this was undoubtedly the fact that the discourse of that time, although it supplied the basis for an IRP, still did not accept the end of CUT's autonomy in relation to the international trade union confederations. Therefore, once the CCSCS was supported by Orit and once Orit was a regional organisation of the ICFTU, it made little sense for the CUT to commit itself ante tempus to this organisation. Yet although it could not or did not intend to commit itself in advance to a particular international trade union confederation, the CUT kept this open as a possibility for a further three years: "it will be up to the national leadership elected by the 3rd Concut to disseminate broad discussion of the different visions and organisations that exist in the trade union movement worldwide, so that the 4th Concut can develop a policy that further strengthens our relations with the international trade union movement" (CUT 1988b: 32).

From what has been said so far, it is legitimate to locate the true beginnings of the CUT's IRP in this phase. Moreover, if we analyse in detail the Caderno de Teses for the 3rd Concut (intended as preparation for the Congress), the position of the CUT's main tendency - the Articulação Sindical - can be seen, particularly in relation to international affairs. As Rodrigues reminds us (1990: 108), contrary to the other theses, the Articulação Sindical theses began with an analysis of the international conjuncture, "marked by structural changes in the dynamics of capitalism and by the prospect of a deepening crisis in the world economy" (CUT 1988a: 49). In this adverse climate, the CUT still maintained that "anti-imperialist attitude and popular democratic campaigns depend increasingly on the ability of the working class to organise itself". And despite the innumerable difficulties experienced at the time by the union and the popular movements in articulating the everyday struggle of the workers, it was felt that "the great political advances

${ }^{11}$ Former CUT International Relations Secretary, interview, June 2001, São Paulo, CUT Head Office. 
achieved by workers throughout the Latin American continent are undeniable" (CUT 1988a: 50).

\section{Phase 3: International affiliation}

The third phase of the CUT's IRP began with the 4th Congress (September 1991) and was defined by a major event: the approval for CUT affiliation to an international trade union confederation. The fact that up until then the GUT had not been affiliated to any world trade union organisation had restricted its ability to intervene and influence the international union forums, since participation in these events was by invitation only and basically consisted of salutations and welcoming speeches. The 4th Concut appointed the 5th National Plenary Meeting of the CUT (held in June 1992) responsible for deciding which international union confederation the CUT should join and for defining a clear IRP that would provide the CUT with greater potential for international intervention and more influence over the processes of economic and social change that were taking place (CUT 1991a: 8).

The main trends in international events that attracted the attention of the CUT during the 4th Concut as well as the 5th National Plenary Meeting were as follows: i) the growing inequality between rich and poor countries; ii) the economic stagnation in Latin America, accompanied by the advance in neoliberal policies based on the internationalisation of the economy and overseas trade, the privatisation of state companies and public services, flexibility in the employment market, wage cuts and rising unemployment; iii) the disappearance of the Soviet Union and the weakness of socialism; iv) the immediate effects of the economic internationalisation; the fragmentation of solidarity ties amongst workers; the significant changes within the profile of the working class, testified by the "relative loss of importance of the working and peasant class within the trade union movement" (CUT 1992: 14); the new forms for the organisation of production, associated with increased automation; or even the production transfers between countries, according to the new international division of labour; v) regional integration initiatives - led in particular by the United States of America (USA) and also involving Canada and Mexico - and sub-regional integration initiatives - such as Mercosur; vi) the discussion of the future challenges to the international trade union movement, related to the need to overcome falling union membership or to re-think the traditional forms of trade union co-operation, frequently based on declarations of solidarity and very often restricted to "ideology and trade union concepts" (CUT 1992: 17).

The strategy for international activities defined by the 4th Concut (CUT 1991a: 10) was based on the following priorities: a) deepening relationships with trade union confederations throughout the world, supporting joint actions on issues of interest to workers, such as combating neoliberal policies, the campaign for non-payment of the external debt or the fight against the negative effects of regional integration; b) giving priority to union activities in Latin America and union cooperation with the Latin American trade union confederations; c) promoting joint initiatives between different trade union organisations in different countries, but belonging to the same multinational company, in order to create an international exchange amongst workers based on the workplace; d) reinforcing international solidarity and strengthening the GUT solidarity commission; e) deepening the debate on the 
international trade union movement with the aim of defining, in political and organisational terms, the CUT's relationship with the international trade union movement.

It was precisely this last priority of CUT international activity that constituted the major new event (confirmed by the 5th CUT National Plenary Meeting in 1992). With the international affiliation, new priorities for international activities were established: the intensification of relationships with Latin America; the deepening of bilateral relationships with the European trade union confederations; the development of actions articulated through workplace organisations; the interiorisation of international relations by the various CUT levels (CUT 2003e: 52-53). The formation of an "International Collective" played an important part in helping to achieve this last priority, which was consolidated over the coming years, with the changeover from

"the management of Osvaldo Bargas to the management of Kjeld Jakobsen. [...] Although it is not a forum for political decision-making, it can act as an arena for the exchange of ideas and experiences, so that the international policy of the CUT can be harmonised with those of the sectorial federations. This is an important experience in terms of socialisation and interiorising the international debate within the national organic levels of the CUT." 12

\section{Phase 4: The defence of Mercosur and the fight against the FTAA}

Contributions towards defining a CUT strategy for Mercosur began to be defined between the 4th and 5th CUT Congresses. During this time, discussions were based on "defending the democratisation of the decision-making mechanisms of the government supranational organisations' that had emerged as a result of integration between Argentina, Brazil, Paraguay and Uruguay", with the aim of "providing a social dimension to the integration of the regional markets" (CUT 1992: 39). This phase was based on more effective action and campaigning for a place for trade unionism within the process of regional integration and on the leading role played by the GUT within the activities of the trade union confederations in the Southern Cone countries. If, during the 4th Concut - which was very much dominated, as already stated, by the issue of international affiliation -, the focus was already on the CUT's activities in Mercosur and the need to democratise the debate on the integration process (CUT 1991a: 17-18; 1991b: 4-5; 1992: 4-7; 1993: 53-54) ), $^{13}$ during the 5th Concut even greater attention was paid to international affairs and to Mercosur in particular. Faced with an integration project "based on commercial liberalisation" (CUT 1994b: 6), the CUT slogan for Mercosur was "let's make our own integration" (CUT 1994a: 29; 1994b: 38) or, in other words, the search for an effective arena for union activity. For the CUT, although the four Mercosur

12 Former SRI/CUT adviser-coordinator, interview, June 2000, São Paulo, Cedec.

13 According to Veiga (1993: 202-203), following the 4th Congress, the CUT adopted two strategies: on the one hand it sought to combat the forms of entrepreneurial integration which had absolutely no respect for social integration and the interests of the workers; and, on the other hand, it created an internal discussion group to promote CUT actions in the Mercosur labour subgroups which had a more decisive impact on labour issues. 
countries were all confronting numerous attacks on workers' rights (restrictions on the right to strike; the outsourcing of work-force; rising unemployment; salary cuts; etc.), there were also several major differences related to demographic density, geographical area, agricultural and industrial development, foreign trade, financial and foreign exchange policies and, obviously, labour relations. According to the CUT, the economic and social differences that existed between the Mercosur countries tended to increase in direct proportion to the effects of the transitions taking place in each country's model of development, since they were moving from a form of industrialisation based on "substitution of imports" (from the 1940 s to the 1970 s, governed by the internal market and the links between the state and international capital) to the "transnationalisation of the economy", from the 1980s onwards. From the CUT's point of view, this model represented access to the international market, profound changes in the employment market, the privatisation of public services, further denationalisation of the economy and the weakening of union rights.

In the face of a critical attitude towards a regional project that reduced the role of the state and strengthened the role of the market, the CUT argued that Mercosur should be governed by social legislation. It therefore called for unified trade union action in Mercosur, namely in sectorial terms: "the realisation of sector negotiations, the defence of trade union rights and the implementation of regional collective bargaining in the companies and productive segments" would translate into "the elaboration and implementation of sector policies for Mercosur that would ensure the intervention of the CUT, as an organised social force, in defining the integration process" (CUT 1994b: 41). Following recommendations made within the context of the CCSCS, the 5th Concut called for a Charter of Fundamental Social Rights for Mercosur, to include: freedom of organisation and collective bargaining; the right to strike; and the introduction of new topics in labour relations (e.g. female labour, the environment, health and safety, professional qualifications, etc.).

The 6th Concut (August 1997) followed up this argument for action with continued criticism of the capitalist system, even though, strangely enough, the space dedicated to discussion of international affairs was reduced. The objectives of the CUT's IRP continued to be based on Latin America and focused on the search for joint solutions to common problems arising out of the advance of neoliberal policies in the region, such as unemployment, wage cuts and casual labour. The main CUT lines of action (1997b: 76-77) aimed to achieve the following: increased representation for Orit in the American continent, as a means of promoting a joint campaign against neoliberal policies; the strengthening of bilateral relationships in Latin America with trade union confederations facing similar challenges to those of the CUT; encouragement to the CUT sector organisations to coordinate their international activities within the regional structures of the International Trade Secretariats (ITSs); the fight against privatisation, casual labour, the external debt; the defence of jobs, salaries and union rights; the strengthening of the role of the CCSCS in articulating the campaigns in the region, ensuring the fight against exclusion and promoting joint campaigns; etc.

However, these priorities for Latin America were accompanied by a strategic priority that the CUT had outlined previously (CUT 1992: 31; 1994b: 34-35), namely the relations with trade union confederations in the industrialised countries 
already confronting the problems of technological modernisation. For the CUT, "neoliberal policies have deepened the contradictions that have turned Brazil into a country that must deal with the challenges of modernity before it has found a solution to its backwardness problems" (CUT 1997b: 77), meaning that relations with trade unionism in the "North" were essential. This call for a closer cooperation with the industrialised countries and with Western Europe was maintained up to the 6th Concut, focusing, in particular, on the CUT initiative to: strengthen exchanges between the CCSCS and the European Trade Union Confederation (Etuc) and relations with the German Deutscher Gewerkschaftsbund (DGB) as well as the Scandinavian, French and even Portuguese trade union confederations ${ }^{14}$ (CUT 1999: 41). The case of the European Works Councils (EWCs) brings us to an experiment which, having been relatively successful in core countries such as Germany, France and Holland, also represents a clear reference point for Mercosur (Barbosa 2000: 8), particularly in relation to the first Mercosur Collective Contract (signed with Volkswagen in March 1999). Perhaps this may also help us to understand why, within the context of the 6th Concut, the topic "South-South relations" - previously referred to in the 5th Concut (CUT 1994b: 33) and also the 4th Concut (CUT 1992: 29) does not appear to have been mentioned ${ }^{15}$. That is to say that, although it had not renounced its ideological principles and it still aimed to strengthen Latin American trade unionism, the CUT seems to have gradually come to accept that, alongside the (ever present) discourse on solidarity with the Third World, discourse on closer relations with the First World and its trade unions was also gaining ground.

The CUT 9th National Plenary Meeting (August 1999) reaffirmed the fight against the globalisation of the economy and defended the re-opening of inter-

${ }_{14}$ At the 9th CUT National Plenary Meeting, the call for improved relations with the Portuguese trade union organisations was a new and even surprising move, since Portuguese trade unionism did not, in fact, form part of the "core" trade union world that the CUT had always aimed to be associated with. Organisations such as the German DGB, the French Confédération française démocratique du travail (CFDT), the Italian Confederazione Generale Italiana del Lavoro or the Spanish Comisiones Obreras were some of the preferred European organisations for CUT internal debates on its trade union structure (CUT 1997a).

${ }^{15}$ Only the topic of "Latin America" was preserved, whereas before in the 5th CONCUT there had been two topics: "South-South relations" and "Latin America". However, this does not in any way imply that "South-South" relations were removed from the CUT's international agenda, since in its directives on international activities this objective was still considered "an essential part of the process of reconstructing international solidarity" (CUT 1997c: 3). Moreover, "it is obvious today that in the process of globalisation the winners are those who have always won, the large industrialised nations who have always been able to steer the world economy. They still remain winners. The only way to obtain a better balance is if the countries of the South manage to make themselves heard, in other words, if they can acquire greater political power. In the case of the trade union movement, this is starting to become a reality - the possibility of the 'South' having more of a voice within the international union organisations and of them all starting to speak the same language" (CUT International Relations Secretary, interview, June 2000, São Paulo, CUT Head Office). In fact the issue of "South-South relations" would be greatly reinforced the following Congresses (since the 7th Concut to the present) and National Plenary Meetings (since de 10th National Plenary to the present). On this purpose, see CUT (2008: 10; 20; 59; 2009: 33). 
national campaigns against the Multilateral Agreement on Investments (MAI) and payment of the external debt. Although the CUT argued in this Plenary Meeting that collective bargaining represented a central issue, on the basis of which it was possible to intensify exchanges with European trade union organisations, it nevertheless did not refrain from blocking the idea of any social contract. In other words, by affirming that relations with union organisations from other countries would only be possible if these organisations were "willing to adopt a perspective of class struggle and class independence, that rejects partnerships with the bosses and social contracts, and condemns privatisation and flexibility in workers' rights" (CUT 1999: 14), the CUT seemed to be contradicting its own national activities which, since the 1990s, had been based on a trade unionism involving bargaining/proposal, in contrast with the $80 \mathrm{~s}$ when the idea of conflict/confrontation predominated (Rodrigues 1997: 41-43, 1999: 88; Boito Jr 1999: 131 ss., 180 ss.; Paoli \& Telles, 2000: 129-130; Véras, 2001: 66, 76; 91-92; 2002: 12; 146-210; Costa, 2005: 427, 2008b: 73). In my view, one possible explanation for that (at least apparent) contradiction between those national and transnational attitudes of the CUT could be explained by the relationship between internal tendencies within the CUT. With the growing and consolidate position of the main tendency - the already mentioned Articulação Sindical-, other internal tendencies more placed ideologically on the left saw reduced their space of influence, particularly at the national arena. My hypothesis is that the main ideological tendency advocated an internal institutionalism at the same time that tolerated an external activism. Of course this doesn't mean that CUT has to faces, one for the national politics and another for the IRP. But, at least, it suggests that was probably easier to be counter-hegemonic outside and more hegemonic inside ${ }^{16}$.

On the other hand, another aspect which, although not new, was a feature of the 9th National Plenary Meeting (1999), in contrast with the 6th Concut (1997), was the defence of the continental unity of the workers in their fight against the FTAA, whose objective was to "simply transform the entire hemisphere into a North American back-yard, with a free market for its capital and products and super-exploitation of the working class" (CUT 1999: 40). As a result of ICFTU initiatives, the CUT reaffirmed its defence of the "social clause" as an objective in the fight against social dumping and as a means of globalising social rights in the face of the economic globalisation. In 1998 the creation of the CUT "Social Observatory"17 - which aimed to investigate the behaviour and strategies of the multinational companies operating in Brazil in terms of their accomplishment to ILO social and environmental conventions - was a strategic tool chosen by the CUT in the fight against social dumping.

${ }^{16}$ On this regard, the argument supported by Francisco de Oliveira concerning historically the Brazilian trade union movement seems quite appropriate. In his view, "if in the past, unionist movement born in São Bernardo was anti-hegemonic in its anti-dictatorial politics because it aspired to the benefits of private welfare with the auto-makers, thus being pro-hegemonic at the level of sociability and of the production of an 'industrial cultur' (in the Gramscian sense of 'Americanism'), at the present moment it is pro-hegemonic at the political level, while its proposition for a national metalworkers contract is anti-hegemonic at the level of sociability" (Oliveira 2006: 338-339).

${ }^{17}<$ www.observatoriosocial.org.br>. 
At the same time, fighting the FTAA served as a strategy to defend Mercosur, and the list of CUT demands for Mercosur included the following: the adoption of a social dimension to guarantee the free movement of citizens; a Social Charter outlining fundamental workers' rights; the construction of democratic structures for popular participation; the genuine integration of individuals, based on economic development in the region, accompanied by social justice. Moreover, this was the line taken by the 7th Concut (August 2000) in opting for union mobilisation as a means of combating the rising pessimism resulting from the Mercosur crisis.

It may be argued that at the beginning of the 21 st century there has not been such a great dependence on the CUT's IRP in relation to the "Mercosur issue", given that the Mercosur agenda has become increasingly influenced by the FTAA agenda: "the FTAA has not only steamrollered the agenda for the re-launch of Mercosur but also altered the Argentinean position in negotiations with Brazil" (Arbix \& Veiga 2001). However, since "in our case we are trying to work with Mercosur as a factor that might offer a minimum of resistance to the straightforward expansion of the North American Free Trade Agreement (Nafta) throughout the rest of the continent" and, as "we have a stronger presence in Mercosur than in any other body"18, it still remains important. Even though at the 7th Concut less time was devoted to discussing international matters, in contrast with the previous Congress, there were still denunciations and predictions of somewhat fatalistic scenarios for Latin America in general and more specifically for Mercosur, arising out of the financialisation of wealth, the great expansion in the flow of trade and investment, the unemployment crisis, the increasingly unequal distribution of the world's resources, etc. In order to deal with this and other adversities, the CUT seemed to be testing out campaigning styles that reflected a "return to the past": on the one hand, by stressing an anti-imperialist stance typical of the early days of the CUT which also, to a certain extent, recovered the ideological force of this period; and, on the other hand, as a complement to this, by making sure the issue of the "external debt" once again featured strongly on the CUT agenda. In the last analysis, for the CUT, organisations such as the IMF and the World Trade Organisation (WTO) have developed an "unprecedented policy of rapaciousness and attacks on the sovereignty" of countries such as Brazil and Latin America in general, by imposing a truly aggressive recolonisation in which "mechanisms such as the external debt, the commercial and financial opening up, privatisation and denationalisation of the economy are bleeding entire continents dry, for the benefit of a handful of international oligopolies" (CUT 2001a: 11).

The climate of instability surrounding Mercosur has given rise to uncertainties about its future, as well as the future of the CUT in Mercosur. In this sense, the strengthening of union organisation in the Southern Cone countries through the CCSCS has become a matter of interest for the CUT, in order to ensure that Mercosur does not come to represent the "used card" in transnational trade unionism. The fact that the CCSCS itself was not formed as a result of Mercosur but rather as "an unprecedented initiative in the Latin American trade union movement" (Veiga 1993: 200) prior to the emergence of that regional block, is

${ }^{18}$ CUT International Relations Secretary, interview, June 2000, São Paulo, CUT Head Office. 
therefore an incentive for trade union action in the new millennium. However, it should be remembered that the CCSCS only acquired "a new impetus with the creation of Mercosur" (Véras 2001: 70), especially since this provided "an arena for cross-border union action" (Castro 2000: 111). For the CUT, the challenge of engaging in joint action with other unions within the CCSCS is even greater, given that the CUT was one of the founders of the CCSCS and played a leading role within it, consequently bearing a greater responsibility for ensuring that the CCSCS establishes itself a "key body in the articulation of regional policies" (CUT 1997c: 4) and the "main instrument for action in Mercosur" (Padrón 1999: 361). The appointment (in September 2003) of Rafael Freire (former CUT International Relations Secretary in the first half of 2000 and the first half of 2003) to the post of Secretary General of the CCSCS certainly reinforced that challenge.

\section{Phase 5: Towards an international social movement trade unionism?}

Within the divisions I have proposed for the various phases of the GUT's IRP, there are evident links between some topics. This means that they are not rigidly separated from each other. Sometimes what really exists is a prolonged development over several phases, accompanied by new orientations. For example, in proposing that, particularly since 2001 (when the first World Social Forum, WSF took place), the CUT has entered into a new phase in its IRP - which I term the phase of "international social movement trade unionism"19 - I am far from suggesting that it has broken entirely with the previous phase, since in the 5th phase a dual discourse of support for Mercosur and attacks on the FTAA was emphasised. Moreover, as an argument that justifies the links between phases, I would even say that this 5 th phase - which, I stress, in my view only really became effective after 2001 (since it was the 1st WSF that confirmed on a worldwide scale the CUT practice of broad social alliances), although Seattle (by the end of 1999), where the CUT had also been present, had been the first clear global sign of the gathering of an "anti-globalisation political force" (CUT 2003e: 108) - is the corollary to a "period of great diversification in the international activities of the CUT" which had already been registered since 1995 (CUT 2003e: 77).

I believe that the CUT 10th National Plenary Meeting (May 2002) was illustrative of this continuity between phases. In fact, at this Plenary Meeting the CUT stated that "popular mobilisation against globalisation has assumed new dimensions since Seattle in the USA, in November 1999, and acquired the characteristics of an international demonstration", given that "its world political impact already forms part of the strategy of the social movements in Brazil and other countries". Thus, discussions on international policy at the 10th National Plenary Meeting would be aimed at updating and systematising "our directives on intervention in this area" (CUT 2002: 1). Also in the Caderno de Teses for the 8th Concut, Rafael

19 According to Moody (2001: 276; 290), social-movement unionism - which "implies an active strategic orientation that uses the strongest of the society's oppressed and exploited, generally organized workers, to mobilize those who are less able to sustain self-mobilization: the poor, the unemployed, the casualized workers, the neighborhood organisations" (on this see also SeIdman 1994) - is perspective "to be fought for on an international scale". 
Freire Neto (who replaced Kjeld Jakobsen as CUT International Relations Secretary during the first half of 2003) and Rosane da Silva reaffirmed that Seattle had even inaugurated a new phase: "of social movements against neoliberal globalisation". These movements made it possible to strengthen the broad agenda of campaigning and popular struggle that challenged the world economic and political order and its predatory nature, social exclusion in every countries, patriarchy as a system which oppresses women, as well as racism and restrictions on freedom of sexual orientation. Following the escalation of the North American military offensive against Iraq, anti-war demonstrations were held all over the world, both before and after the war started (on 20th March 2003). In this area as well, the CUT "should maintain and intensify its international strategy of broad social alliances" (CUT 2003a: 33).

The Texto Base (main policy document) of the national leadership of the CUT presented at the 8th Concut continued to stress that the building of a new society required greater investment in "streets and people mobilisations" and that there was an urgent need to "unify the struggle around campaigns such as the preservation of jobs, the reduction of the working day and against the FTAA annexation project" (CUT 2003b: 3). It was therefore argued that the CUT should undertake the following: participation in mass continental demonstrations against the FTAA, thus strengthening the Hemispheric Social Alliance (HSA); the reinforcement of information and education within the CUT on the FTAA and free trade; "support for the following projects which are in their procedural stages in the National Congress: the project from Senator Saturnino Braga to stop negotiations with the FTAA; and the project by the former Deputy Aloísio Mercadante proposing a referendum on the FTAA" (CUT, 2003b: 7).

Within the context of the fight against neoliberal globalisation, opposition to the FTAA became even more central to the CUT's discourse. The direct opposition of the GUT to the FTAA intensified, particularly between the 6th and 7th Concuts, since "it became increasingly clear that the USA's negotiating strategy for the FTAA was to turn it into an extension of the Nafta, spanning the rest of the continent" (CUT 2002: 5). The reasons for trade unions and other social movements to reject it therefore increased: the FTAA signified a new wave of economic liberalisation; the inequalities between the countries involved meant that a fair agreement could not be reached; the USA was not going to change its trading policy; the Brazilian economy had a lot to loose; the FTAA would represent the "Mexicanisation" of Brazil; the FTAA would destroy Brazilian national sovereignty (Jakobsen, apud Mello 2002: 6). Therefore, "the CUT must spearhead mobilisation in Latin America. As an attitude we demand of the government and as direct action by the trade union movement and the other popular movements, in solidarity with the same sectors in other Latin American countries, we must act to build a strong movement, on a continental scale, to stop the FTAA". This would establish the foundations of a political and economic plan that would create "a solidary integration amongst peoples" (CUT 2003c: 49).

Especially after the Mar del Plata Summit (November 2005) - where it was evident the "defeat" of the Área de Libre Comercio de las Américas (Alca) project visà-vis the popular unity promoted by the supporters of Mercosur (CUT 2006: 9) additional reasons to believe on this customs union grew up. As a fact, Mercosur 
will continue to function as a reference point for CUT's trade unionism, since it continues to defend "the strengthening of Mercosur and Brazil's bilateral and multilateral relations with other nations in Latin America and the rest of the world" in order to strengthen Brazilian sovereignty (CUT 2003c: 49). According to Fátima Mello (2002: 3), the Brazilian government claims that the FTAA is an option and Mercosur is a destiny. Whilst it is true that options may be controlled (and, in this sense, avoided), destiny (being inevitable) is not always easy to control and it is therefore logical to think of Mercosur as a customs union that needs to be "deepened", particularly in terms of its social dimensions. Moreover, in terms of CUT trade union discourse this would make more sense, since resistance to the FTAA would imply that Mercosur (the Mercosur of the "social conquests") is seen as a destiny that is not only unavoidable but also preferable. This had already been made clear in February 2003, in a letter sent by the CUT to the Brazilian Foreign Office Minister, Celso Amorim. In it, the CUT praised the priority given by the Lula government to Mercosur: "on the basis of Mercosur we should speed up negotiations with the Andean Community and speed up the debate proposed by Brazil within the Associação Latino-Americana de Integração (the Latin American Integration Association) so that this can provide us with a mechanism and a context for reaching a trade agreement in South America". In addition, "we also believe that Mercosur should coordinate with other developing countries such as India, South Africa and China to press for a review of the WTO Trade Related Investment Measures and Trade Related Intellectual Property Rights agreements, as well as an end to subsidies and non-tariff barriers as practised by the United States, Canada, the European Union and Japan" (Informe ALCA, 2003: 7).

Whilst supporting Mercosur and fighting the (presently "dead") FTAA, the current phase of CUT's IRP is based on the "broad unity of the international social sectors" (CUT 2001b: 20; 2002: 3). As the CUT International Relations Secretary observed at the 3rd WSF:

"The political objectives and mutual respect of the organisations who form this common intervention is what guides us and has enabled us to be a part of the organisation of this World Social Forum since the beginning, as we were in Seattle, as we were in Genoa, as we were in various other demonstrations that took place around the world. We, in the CUT, want a trade union movement that is really strong, in touch with the present day and organised internationally in alliance with other movements." ${ }^{20}$

In other words, the CUT considers trade unionism as the most important social actor within the social movements. One area in which the trade union has been able to reinforce its intervention is that of the fight against the multinational companies, "the true driving force behind neoliberal globalisation" (CUT 2002: 2; 2003b: 7). However, this has not only been achieved in conjunction with other trade union organisations, through projects such as "Acção frente às multinacionais:

${ }^{20}$ Statement from the panel "Sindicalismo e movimento social vs capitalismo neoliberal: necessitamos de novas formas de organização contra novas formas de capitalismo?" "“Trade Unionism and social movements vs neoliberal capitalism: do we need new forms of organisation to confront new forms of capitalism?", Porto Alegre, 26 January 2003); see also NeTo (2004). 
construindo redes sindicais nas empresas multinacionais" ("Action against multinational companies: constructing trade union networks in multinational companies") ${ }^{21}$ or though initiatives to implement the Organisation for Economic Co-operation and Development $(\mathrm{OECD})^{22}$ directives for multinational companies (CUT 2003e: 115117). It has also been achieved through links with other organisations in civil society. For example, the monitoring of the extent to which companies operating in Brazil comply with basic ILO social and environmental standards is a task that is carried out by the CUT "Social Observatory" (which in 2002 acquired autonomous legal status), implying that this is work with an international impact that involves the combined actions of both trade union and non-trade union entities. In other words, whilst functioning as an important support and information-gathering mechanism for the SRI/CUT, the Social Observatory also, in my understanding, helps pave the way towards an international social movement trade unionism. The fact that, for the first time, in the 8th Concut (June 2003), non-trade union representatives were present amongst the delegates as guests confirms the opening up of CUT's IRP to transnational policies and suggests the defining of new challenges in conjunction with other international social movements.

This trend was confirmed at the 9th Concut (June 2006). As a matter of fact, the "relations with other social movements" was, among other issues (like wage, employment and inclusion issues, democracy and public policies, and the reinforcement of the GUT structure and organisation) one of the main axis for the "action policy" of the CUT 2009 (CUT 2006: 81). And the same line of thought was also evident during the 12nd National Plenary Meeting (August 2008) and in the context the 10th Concut (August 2009). According to the GUT, it is urgent to support regional, continental and global political actions. Especially within the context of the WSF that goal is shared with other social movements. With that purpose, CUT will promote a complete and common global calendar of struggles (CUT 2009: 34-35).

$$
* * *
$$

It is particularly fair to recognize that CUT is in the frontline of what I called a leadership in regional transnational trade unionism (Costa 2005; 2008b). That's the reason why, from the first moment, GUT decide to became member of the new configuration of the international trade unionism, resulted from the constitution (in November 2006) of the already mentioned new "Labour International": the International Trade Union Confederation (Ituc). Namely through the work of the regional organisation of the Ituc in the Americas - the Ituc-Regional Organisation

${ }^{21}$ This is a project that aims to create trade union networks for the exchange of information amongst workers in the various different factories owned by the multinational companies operating in Brazil, in order to create a dialogue with the company and strengthen the workers' position in negotiations with the multinational companies (CUT 2003d: 1; 2006: 65-66; 2008: 59; 2009: 34-35). See also the informative bulletin periodically edited by the CUT, with the support of Dutch Federatie Nederlandse Vakbeweging (FNV).

${ }^{22}$ Taking advantage of the fact that at the end of 1999 Brazil formally agreed to these OECD directives, the CUT has begun to exert pressure on the multinational companies to accomplish international standards relating to the world of work. 
for the Americas -, GUT believes that is possible to strengthen trade union and social struggles in Americas. At the same time, GUT has been trying to consolidate its international trade union project, through the deepening of trade union and social alliances and the South-South relation, and by acting in a propositive way in several spaces: the Southern Initiative on Globalisation and Trade Union Rights; the Americas Trade Union Forum, the World Assembly of Social Movements, the Hemispheric Social Alliance, the Brazilian Network for the Peoples Integration, the World Social Forum (WSF), the trade union networks within multinationals, the cooperation with Global Union Federations, etc. (CUT 2008: 59; 2009: 32-33).

However, despite the participation in these (and other) initiatives, in my research work I realised that the IRP played a relatively secondary role in the CUT's policies in general, once the "international issues" are not among the CUT priorities. One of the several leaders of the international department I interviewed suggestively told me that if we made the exercise of measuring the strength of IRP in a scale from 1 to 5 probably the IRP only represents 2 or even 1! This means that CUT is a national organisation and that, above all, are the national pooling effects that most mobilizes the GUT. Than, it would certainly be urgent to reinforce within the CUT's international structure (i.e., among the national organisations affiliated with CUT) a dynamic of debates surrounding international relations, which would maximise the necessity of a "global trade unionism" vis-à-vis the "global capital". But, of course, it would be unfair to consider that IRP is a residual policy in the set of CUT policies. Not only because in CUT's history several presidents of the CUT were also (in different moments) international secretaries (and this means, at least, a symbolic recognition of the importance of the IRP), but also because, as I have said elsewhere (Costa 2008b: 52), IRP is an "extension" policy of the national CUT concerns: solidarity among workers in local place, struggle against social injustices, respect for human rights, combating anti-union employer practices, etc., etc. And that's the reason why I tried to demonstrate not only the autonomous existence of the IRP, but also the possibility of making distinctions between its phases.

The IRP of the CUT is still today oriented towards a counter-hegemonic trade unionism, confirming the principles and ideological orientations of the Brazilian organisation. Anyway, the double election of Lula as President of the Republic produced inevitable influences in CUT's behaviour, once that political fact came to reinforce, at least nationally, the institutionalism of the CUT (Costa 2008b: 77). Of course this proximity between CUT and PT was inevitable since the foundation of the CUT, and Lula was himself a founding father of both PT and, consequently, of the CUT. Lulas' election was, than, saw as a victory not only for workers as for labour relations in general. Contrary to Fernando Henrique Cardoso governments, in Lula's governments became possible the opening of spaces and institutions of negotiation, the democratisation of social movements, or the recognition of the trade union centrals (CUT 2009: 13).

Both in the CUT speech and practices the values of socialism didn't disappear, once those values belong to the CUT's character (CUT 2009: 36). However, in a certain way, those values seem to be more relevant internationally that nationally, in part as a result of the national ideological compromise between CUT and PT (the number of trade unionist absorbed by Lula's government was an undeniable 
prove of that!). According to Roberto Véras, the national incentives to social dialogue and labour reform promoted by Lula's government reduced at the same time the possibilities for an audacious democratic project (Véras 2007: 67). In my opinion, the IRP could, than, recover or "compensate" the national institutionalism of the CUT, observable in the appeal to a reinforcement of the role of negotiation with private and public employers and with the government (CUT 2006: 46-47). The participation of the GUT in international forums - in several cases in cooperation with other civil society organisations (which was quite evident during the battle of the HSA against FTAA and especially within the context of WSF) -, could be understood as a good step to return to the historical activism of the CUT. Recovering that combativeness is probably the best way to overcome the constraints on international trade unionism and a good way to reinforce the CUT's IRP.

December 2007 and May 2009

Hermes Augusto GOSTA University of Coimbra, Faculty of Economics Centre for Social Studies

\section{References}

Arbix, G. \& Veiga, J.P.C. 2001, "A crise do Mercosul e o abraço de urso da Alca", Gazeta Mercantil, São Paulo, 23 April 2001.

Barbosa, M. dos Santos 2000, "Sindicalismo no Mercosul : com os pés na estrada", comunicação apresentada no Seminário Internacional CUT : discutindo novos caminhos, São Paulo, Sindicato dos Químicos e Plásticos, 14 June 2000: 1-8.

Bargas, O. 1991, "Perspectivas do movimento sindical internacional e os desafios colocados para a CUT", in Centro ecumênico de documentação e informação (CEDI), A CUT e o movimento sindical internacional, Rio de Janeiro-São Paulo, CEDI: 9-32.

Borto Jr, A. 1999, Política neoliberal e sindicalismo no Brasil, São Paulo, Xamã.

Castro, M.S. Portella de 2000, "Movimento sindical no Mercosul: Trajectória e perspectivas de acção", in J. Lorenzetti \& O.L. Faccio (eds), O Sindicalismo na Europa, Mercosul e Nafta, São Paulo, Ltr/Escola Sul da CUT: 103-135.

Castro, M.S. Portella de \& Wachendorfer, A. 1998, "El sindicalismo del Mercosur : su trayectoria y sus perspectivas en un contexto de ampliación comercial hemisférica", in M.S. Castro \& A. Wachendorfer (eds), Sindicalismo y globalización: La dolorosa inserción en un mundo incierto, Caracas, Nueva Sociedad: 13-38.

Cosatu 2001, "A strategic perspective on the international trade union movement for the 21st century: a minimum platform to reposition the ICFTU to meet the challenges of the new millenium", in Global Solidarity Dialogue (<www.cosatu.org.za/docs/2001/icftu-mr.htm>), accessed on 12 October 2001.

Costa, H.A. 2005, Sindicalismo global ou metáfora adiada? Os discursos e as práticas transnacionais da CGTP e da CUT, PhD in Sociology, Coimbra, Faculty of Economics, 854 p.

2006, "Enlarging the canon of labour internationalism", in B.S. Santos (ed.), Another production is possible: beyond the capitalist canon, London, Verso: 243-277.

- 2008a, "A nova confederação sindical internacional", Janus (Anuário de Relações Exteriores, Lisbon), UAL/Público.

2008b, Sindicalismo global ou metáfora adiada? Discursos e práticas transnacionais da CGTP e da CUT, PhD in Sociology, Coimbra, Faculty of Economics, 347 p. 
2009, “A nova 'Internacional operária' : rumo a uma 'sociedade laboral global'?”, X Congresso Luso-Afro-Brasileiro de Ciências Sociais, Sociedades Desiguais e Paradigmas em Confronto, Braga, Universidade do Minho, [available at <www.xconglab.ics.uminho.pt $>$ ].

CUT 1984a, I ${ }^{\circ}$ Congresso Nacional da Classe Trabalhadora, Rio de Janeiro, Tempo e Presença Editora.

- 1984b, Fornal da CUT, Ano II, 1, São Paulo, CUT.

1986, Resoluções do $2^{\circ}$ Concut, São Paulo, CUT.

1988a, Caderno de teses para o $3^{\circ}$ Congresso da CUT (2 ${ }^{a}$ edição revista e ampliada), São Paulo, GUT.

\section{8b, Resoluções do $3^{\circ}$ Concut, São Paulo, CUT.}

1991a, Resoluções do $4^{\circ}$ Concut, São Paulo, CUT.

1991b, Os trabalhadores e a constituição do Mercosul, mimeo, São Paulo, CUT/DESEP, 1-6.

1992, Política de relações internacionais, São Paulo, CUT.

1993, "Elementos para a estratégia da CUT no Mercosul", Cadernos da CUT - jurídico e relações sindicais, $8,52-55$.

1994a, Tese base para o $5^{\circ}$ Concut, São Paulo, CUT.

1994b, Resoluções do $5^{\circ}$ Concut, São Paulo: CUT.

1997a, Como se organizam os trabalhadores da Europa?, São Paulo, CUT.

(1997b, Resoluções do $6^{\circ}$ Concut, São Paulo: CUT.

1997c, "Directrizes de actuação internacional CUT, 1997-2000", <www.cut.org.br/al001. htm>, 1-7, accessed on 28 April 2000.

1999, Resoluções da $9^{a}$ Plenária Nacional da CUT, São Paulo, CUT.

2001a, Resoluções e imagens do $7^{\circ}$ Concut, São Paulo, CUT.

2001b, Texto base da $10^{a}$ Plenária Nacional, São Paulo, CUT.

2002, "Relações internacionais", Resoluções da 10ª Plenária Nacional, <www.cut.org.br/ 10plencut/polper.htm>, 1-6, accessed on 21 March 2003.

2003a, Caderno de teses. Análise da conjuntura e balanço da gestão 2000-2003, $8^{\circ}$ Concut, <www. cut.org.br>, 1-36, accessed on 2 April 2003.

2003b, Texto base da direcção nacional, $8^{\circ}$ Concut, <www.cut.org.br>: 1-54, accessed on 2 April 2003.

2003c, Resoluções do $8^{\circ}$ Congresso Nacional da CUT, <ww.cut.org.br>: 1-161, accessed on

15 October 2003.

2003d, Projecto «Acção frente às multinacionais. Construindo redes sindicais nas empresas multinacionais », <www.cut.org.br/SRI/projeto_CUT_FNV.htm>, 1-3, accessed on 13 June 2003.

2003e, A politica internacional da CUT. História e perspectivas, <www.cut.org.br>: 1-132, accessed on 4 July 2003.

2006, Resoluções do $9^{\circ}$ Concut, São Paulo, CUT.

2008, $12^{a}$ Plenária Nacional. Caderno de Resoluções, São Paulo, CUT.

2009, Caderno de teses do $10^{\circ}$ Concut, São Paulo, CUT.

Giannotti, V. \& Neto, S. Lopes 1990, CUT, por dentro e por fora, Petrópolis, Vozes.

Holthoon, F. van \& Linden, M. van der 1988, "Introduction", in F. van Holthoon \& M. van der

Linden (eds), Internationalism on the Labour Movement 1830-1940, vol. 1, Leiden, Brill: vii-xiii.

Hyman, R. 1999, "National industrial relations systems and transnational challenges: an essay in review", European Fournal of Industrial Relations, V (1): 89-110.

IGFTU 2004a, "Towards unification: new trade union international could be created by 2006", $<$ www.icftu.org/displaydocument.asp?Index $=991221038 \&$ Language $=E N>$ : 1-3, accessed on 13 December 2004.

— 2004b, "Globalising solidarity: congress approves the creation of a new international trade union confederation", <www.icftu.org/displaydocument.asp?Index=991221094\&Language =EN>: 1-2, accessed on 13 December 2004.

INFORME ALCA 2003, 7 March, <cesint@uol.com.br>: 1-8. 
Lambert, R. \& Webster, E. 2006, "Social emancipation and the new labor internationalism: a Southern perspective", in B.S. Santos (ed.), Another Production is Possible: Beyond the Capitalist Canon, London, Verso: 279-320.

Mello, F.V. 2002, "Brazil and the FTAA - the state of the debate since Lula's victory", Estudios sobre el ALCA, (II) 1-7, <www.asc-has.org>, accessed on 17 January 2003.

Moody, K. 2001, Workers in a lean world: unions in the international economy, London, Verso.

NAsh JR, B. 1998, "Globalizing solidarity: praxis and the international labor movement", fournal of World-Systems Research, <http://csf.colorado.edu/wsystems/jwsr.html>, IV (1): 1-3, accessed on 30 September 1999.

Neto, João Vaccari 2004, "A globalização da sociedade civil", <www.cut.org.br/secretarias/ sri_internacional.htm>, accessed on 28 January 2005.

Oliveira, F. de 2006, "Who is singing L'Internationale again? A Brazilian illustration", in B.S. Santos (ed.), Another production is possible: beyond the capitalist canon, London: Verso, 321-351.

PADrón, Á. 1999, "O sindicalismo latino-americano e os processos de integração regional do Cone Sul”, in DIEESE, ed., Emprego e desenvolvimento tecnológico: Processos de integração regional, São Paulo, DIEESE: 349-362.

Paoli, M.C. \& Telles, V. da Silva 2000, "Direitos sociais: Conflitos e negociações no Brasil contemporâneo", in S.E. Alvarez, E. Dagnino \& A. Escobar (eds), Cultura e política nos movimentos sociais latino-americanos. Novas leituras, Belo Horizonte, Editora UFMG: 103-148.

Rodrigues, IJJ. 1997, Sindicalismo e política: A trajectória da CUT, São Paulo, Scritta.

1999, "A trajectória do novo sindicalismo", in I.J. Rodrigues (ed.), O novo sindicalismo: Vinte anos depois, Petrópolis, Vozes: 73-94.

Rodrigues, L. Martins 1990, CUT: Os militantes e a ideologia, Rio de Janeiro, Paz e Terra.

Santos, B. de Sousa \& Costa, H.A. 2005, "Introdução: para ampliar o cânone do internacionalismo operário", in B.S. Santos (ed.), Trabalhar o mundo: os caminhos do novo internacionalismo operário, Rio de Janeiro, Civilização Brasileira: 21-75.

SeIdman, G.W. 1994, Manufacturing Militance: Workers' Movements in Brazil and South Africa, 1970-1985, Berkeley, University of California Press.

Stevis, D. 2002, "Unions, capitals, and states: competing (inter)nationalisms in North and European integration", in J. Harrod \& R. O'Brien (eds), Global Unions? Theory and Strategies of Organized Labour in the Global Political Economy, London, Routledge: 130-150.

Stevis, D. \& Boswell, T. 2008, Globalization and Labor: Democratizing Global Governance, Lanham, Rowman \& Littlefield Publishers.

VeIga, J.P.C. 1993, "Mercosul: Evolução institucional e intervenção sindical", in Projecto IRES/ DESEP, Mercosul: Integração na América latina e relações com a Comunidade Europeia, São Paulo, Cajamar: 197-211.

VÉras, R. 2001, "CUT: 20 anos", Caderno de Formação, 1: 1-112.

— 2002, Sindicalismo e democracia no Brasil: actualizações. Do novo sindicalismo ao sindicato cidadão, $\mathrm{PhD}$ in Sociology, São Paulo, Faculty of Philosophy, Letters, and Humans Sciences, University of São Paulo.

2007, "O sindicalismo e a questão democrática na história recente do Brasil: o que se pode esperar?", in F. Oliveira \& C.S. Rizek (eds), A era da indeterminação, São Paulo, Boitempo Editorial: 49-69.

Waterman, P. 1998, Globalization, social movements $\mathcal{E}$ the new internationalisms, London, Mansell.

2005, "O internacionalismo sindical na era de Seattle", in E. Estanque, L.M. Silva, R. Véras, A.C. Ferreira \& H.A. Costa (eds), Mudanças no trabalho e ação sindical: Brasil e Portiugal no contexto da transnacionalização, São Paulo, Cortez Editora: 219-260. 